\title{
The challenges of kish health tourism: A case study
}

\author{
Jila Manouchehri ${ }^{1}$, Ali Akbar Farhangi ${ }^{2}$ Saeed Someeh $^{3}$, Erfan Shakibaei ${ }^{4 *}$ \\ ${ }^{1}$ Quality Improvement Department, Tehran Heart Center, Tehran University of Medical Sciences, Iran \\ ${ }^{2}$ Faculty of Management, Tehran University, Iran \\ ${ }^{3}$ Kish Free Zone Organization, Kish, Iran \\ ${ }^{4}$ Faculty of management sciences and health economic,Tehran University of Medical Sciences, Iran \\ *Corresponding author E-mail: erfanshakibaei@yahoo.com
}

Copyright $\odot 2014$ Erfan Shakibaei et al. This is an open access article distributed under the Creative Commons Attribution License, which permits unrestricted use, distribution, and reproduction in any medium, provided the original work is properly cited.

\begin{abstract}
Background: Health tourism industry is a new growing market that developing countries have a large effect on it and noticing this subject has been emphasized by the vision of twenty years strategic plan in Iran. On the other hand, increase of the neighbor countries' attention on this profitable market marker to a basic removal need of present challenges in Kish Free Zone.

Objectives: Aim of this paper is to probe about the challenges of Kish health tourism identified in this case study at 2012 by qualitative method.

Methods: Effective variables on health tourism were extracted from relative literature and then, variables in 34 groups were combined as a questionnaire with considering the proximity of concept and content. 14 persons were chosen as expert among the present and previous managers of tourism, healthcare system and health tourism areas by Modulation from simple and snowball sampling. Experts in addition to recognized challenges, expressed how significant is each one of health tourism developing factors and gave their expletive ideas about each challenges by Semi-structured interviews which were analyzed by Content Analysis Method.

Results: The 13 main challenges of Kish health tourism extracted from interviews were related to policy making and planning, substructure and administrative problems, and macro affaires of country.

Conclusions: Kish Free Zone Organization as governance representative in Kish should eliminate the existing challenges of health tourism industry in order to develop Kish health tourism.
\end{abstract}

Keywords: Case Study, Health Tourism, Iran, Kish Free Zone, Medical Tourism.

\section{Introduction}

\subsection{Health tourism}

In recent years, health tourism has introduced as a novel path of business and it has developed by governance shelter [1]. Health tourism is a travel with purpose of receiving healthcare services in other countries as a tourist. This kind of tourism is become to a multi-billion dollar in the world field [2]. "Healthcare services" and "tourism" are tow concepts with which merge and make "health tourism" by Interference and benefit to all of the contributed institutes at health tourism include travel agencies, aviation companies, hotels, transportation system etc. [3]. The noticeable point is growth healthcare services trade stock among other services share of world trade, that was 38\% in 1997 and it was increased until 73\% in 2003 and it has regularly being increased so far. The most noticeable matter about this increasing growth is stock of developing countries among total share from this world market that is $40 \%$ [4], [5]. Health tourism is going to Efflorescence in Asia and will have been expected value of this market grows until 4 billion dollars by 2012 [2], [6].

In recent decades, the number of patients that traveled to abroad for using of health services was increasingly enhanced. The most significant causes for growing health tourism are include: high cost containment of heath care services, long term of waiting queues for receive some medical practice in country of origin [7], ease and financial ability for 
implement a cross border travel, addition medical skills at countries of destination, development of technology, standards and health care systems, aging population in developed countries, internet extension [8], numerous cost difference between costs in countries of origin and countries of destination for health tourists, so that cost for an specific surgery in India, Thailand, or south Africa could be one-tenth lower than same operation in U.S or western Europe [9], growth of population, approximately high wealth and high costs of health care parts in European, Middle east, Japan, Canada and U.S countries [10], low range insurance covering for some treatments such as hip and knee replacement, limit creation by choosing the type of surgery or surgeon [9], tendency of patients for receiving health services with lower cost and higher quality [11], and finally, lower costs in countries of destination [7], [12]. Increasing growth of health tourism has made a potential market for developing countries and some countries have abled to find an appropriate position by use of specific strategies. Health tourists' countries of destination are often developing countries and mostly Asian that the number of them is raising [8]. Saudi Arabia's medical centers earn 227 million Euros by health tourism annual [13]. United Arab Emirates has created health city for gaining the Middle East market and to absorb the Asian health tourism market and it has heavily notified the quality of services [3]. Jordan has chosen the policy of hold down costs for attract health tourists [14], and India and Thailand has captured a suitable market by noncompete for ever prices [12].

Indeed, consideration about impressive factors at health tourism has a significant effect to development of this industry. Cohen in a study at 2008 in Thailand showed that hospital as an important pillar on health tourism promotion should notice to these items: application of high skilled and mature professionals, invest on medical facilities' sector, upgrade the quality of care services, obtain some welfare conveniences such as translator and recreational services [15], [16], and finally, achievement of hospitals in gain international accreditation are the mandatory conditions in health tourism countries of destination. Garcia Altes introduced four sufficient basic factors to develop the health tourism: price, quality, accessibility to services, and appropriate time [7]. Andaleeb also knows informing patients about quality of work, physician's proficiency, and existence of technology and special benefits of hospital to create more tendencies for choosing countries' of destination care services [17]. Also intellectual image of country of destination, perceived value and quality of services have positive correlation with tourists' loyalty on their election [18]. In recent years by increasing of health tourism industry, some bewilderment was brought in this area that causes rework in policy making and wasting human resources [1]. Moreover of problems related to policy making, inadequate information about care services and tourism pack, scant of time, no relative to come with, and solicitous around none satisfying schedule of travel are the most significant preventable elements to cease medical services from medical tourists' point of view [19].

\subsection{Health tourism in Iran}

According to the Iran's strategic plan of twenty years, Iran will achieve to first place in health tourism amongst the Middle East countries [20], and will be commuted to such a need responder for healthcare services in this area and also predicted to has 20 million medical tourist and earn 15 billion dollars by this industry till 2025 [13]. Some researchers have this thought that it should be a national motivation and it is media's duty to inform people and experts about various dimensions of this movement [20]. The main aim of this departure is earning benefits and progression in this area via Iran participation with worldwide markets and introducing it as pioneer of this industry [3].

Beside this upper mandatory policy, Iran has excellent potentials at this industry; Existence of high Cost containment, low quality, and weak healthcare systems in countries of origin. On the other hand, proximity and accessibility to Iran as the country of origin, low cost containment, acceptable quality of care services, and updated diagnostic and therapeutic techniques are the factors to prove Iran's potentials at medical tourism industry [21]. Also existence of 51 universities of medical sciences with 80 years' experience greatly elevates medical area credence in this country [15]. According to cultural heritage organization statistics, 20000 health tourists entered in Iran from Middle East countries and coasts of Persian Gulf in 2007, and result was $12 \%$ revenue from total tourism sector [20]. Hospitals that are involved at medical tourism in Shiraz averagely medicate 50 medical tourists in a year. Most of them come from Arab countries beside the Persian Gulf and among the Arab countries; Oman has the first place by 20\%. Ophthalmology services with $30 \%$ as the most and orthopedic services with $6 \%$ as the least among received medical tourist services. Closeness and similarity of cultures and religious between Iran and countries of destination, also patients' credence feeling to physicians was the most influential elements in order to choose Iran as country of destination by patients received care [22]. As a result, suitable cultural environment in Muslim countries is a strength point for Iran so as to develop medical tourism [13], High level of professional medical sciences, unique vim for fertility treatments, and vigor of complex surgeries are some other conclusive contestable claim hoping for considering Iran as an international care giver [23], [24]. Arab's bazar is the most attractive amongst health tourism worldwide markets. 245 million populations of 17 Arab countries, poverty of professional services and their vigor to spend money at this market has driven them to neighbor countries with medical goals. Recently independent countries are the other absorbable markets for Iran. Rapidly planning wishing to absorb patients from there seems necessary since lack of some proficient facilities and existence low quality of medical services in these countries. On the other hand, the most of these countries have an interested and respectful vision of Iran and also they have acceptable financial situation [24].

Sum of study results expresses the most principal factors at heath tourism in Iran: 
Branding, coordination of related organizations to medical tourism, existence of an inter-organization trustee, policy makers, organizer and supervisor, update of hospital's websites, promotional mobile communications aiming for introducing hospitals, telephone consultation services, publishing of frequent public reports, inquiring from patients about quality of services 10 days later after discharge, focusing on auxiliary services, give some extra facilities like internet access and computer games, using of high technology equipment, being on lower cost containment situation compare with other countries, making clarified asked costs for foreign patients, increase the medical tourist stocks of markets amongst neighbor countries and Middle East countries, improving of medical tourist products and services, pervading the new markets, rendering prominent and proficient services, and being novel at healthcare tourist services[21], [25].

Iran has potential in order to absorb 5\%, approximately 5.2 million dollars of neighbor countries' care costs, which could afford $1.3 \%$ from the total income of non-oil exports. Nevertheless assurance to achieve this purpose needs great attention on medical tourism in Iran [20] beacause Experts believe that not only Iran has many opportunities at health tourism sector, but also face to many challenges mutually [26], [27].

Inconsistency between health tourism trustee organizations, lack of specialized committee in ministry of health and medical education (MHME) and cultural heritage, handicrafts, and tourism organization (ICHTO), lack of a comprehensive data collection system to register medical information related to tourists, non-efficient information system to apprise about Iran capability at medical tourism, and substructure and legal gaps as barriers for developing this industry are causes of Iran's current inappropriate situation at health tourism. Iran's inability in order for unifying management at this industry in Iran [27] contributes Middle East countries such as India, Singapore, United Arab Emirates, Jordan, Turkey, Azerbaijan, etc. to achieve more proper situations than Iran [24].

In spite of services sector that have formed $46 \%$ of gross national product of Iran till now, macro plans for health tourism industry has not been supported by government [24] moreover, at this area doesn't exist any statistics about number of treated or under treatment patients since, in Iran does not exist an authority aiming to confirm and maintain reports related to health tourists [28]. Another effective factor that could change medical tourists' minds is politic consistency and safety of countries of destination that could probably make people to choose another country for receiving care [8]. Expressed conditions are causes of the frequently decrease in Iran's stock at health tourism sector. Consequently, Countries with poor medical bankroll and only by relying on management abilities have entered to this area and gained high credits and theirs market stock is growing every day.

\subsection{Kish free zone}

One growth pathway hoping to develop areas of country with a special climate in Iran is creating trade free zones to be a reason with the intention of simplifying businesses rules to juice up the trade activities at zone. Kish Free Zone is one of these areas established with an approved statue and at Iran's strategic plan its main mission has considered as tourism [29], [30]. Managers and officials as people in charge of affairs in Kish Free Zone express that they have attempted to introduce this area to internal and external tourists as an appropriate destination according to the natural attractions like virgin nature, Coral Sea, clean and beautiful beaches, dominant safety and composure in the island. Unfortunately by all these opportunities there had not been implemented any impressive action toward growth of this industry in this area. As officials of government expressed, absence of enough cognition around opportunities and challenges is the most important obstacle in the track of health tourism industry growth. Since have not been done a conclusive study at this field so far, by identifying opportunities and challenges of health tourism in Kish Free Zone could be expect to offer some suitable proposals for related officials in order to attract more tourists and help to develop this industry.

\section{Method}

This article is a case study with qualitative method in Kish Free Zone at 2012. This research was done at four stages in order:

At first, the effective variables components which effect on health tourism industry extracted by using of existed resources like papers, books, and related thesis. Then variables which were capable to express well-known and specified contents about health tourism were established as a group named "effective factors in health tourism". At the second stage, experts were chosen with combination of simple and snowball sampling regarding to structure of qualitative study. Principal for choosing experts was experience in management (currently or formerly) at fields such as "tourism", "healthcare providers system", and "health tourism". Experts declared their opinions around each of challenges in the form of semi-structured interview. While doing the interview, experts were asked about their opinion about other experts in these fields, adding the new introduced experts were pursued till saturation. After preparing the first list of experts, effective factors in health tourism were given to experts as a questionnaire while doing interview. Experts answered to tow main questions by answering to questionnaire:

- How much is the importance of mentioned factors which are effective in development of health tourism in Kish Island? 
- Which ones of these factors are considered as health tourism challenges of Kish Island by considering the current condition of Kish Free Zone?

14 interviews were done from 14 experts and all the interviews were implemented by one person from the research team at the experts' workplace, average time of interviews was 88 minutes and they were recorded completely. At the third stage results of experts' opinions about the significance of factors were tested by one sample T test and some of which were statistically meaningless were eliminated (Test value $<75 \%$ ). At the fourth stage challenges were separated from other factors regarding to experts' opinions and simultaneously, were analyzed (by observance of experts' additional opinions and findings of related researches) by content analysis method.

\section{Results}

At the first step, 149 effective variables on health tourism were extracted by using of related theoretical resources then, were synthesized according to proximity of concept and content. Therefore, 34 effective factors on health tourism were gathered totally. An instance of this procedure is showed at table 1.

Table 1: The Pathway of Merging Extracted Variables Together from the Scientific Related Resources with References

\begin{tabular}{|c|c|c|}
\hline Factors & Variables & References \\
\hline $\begin{array}{l}\text { Right choosing of market goals and existence of a } \\
\text { marketing strategy }\end{array}$ & $\begin{array}{l}\text { - } \quad \text { Lack of allied marketing at medical tourism } \\
\text { - } \quad \text { Right choosing of the market target } \\
\text { - Creation of a health tourism marketing strategy at micro and macro } \\
\text { level } \\
\text { - } \quad \text { Existence of marketing strategies } \\
\text { - } \quad \text { Uspropriate marketing strategies } \\
\text { inauguration of representative bureaus in foreign countries. }\end{array}$ & $\begin{array}{l}{[26]} \\
{[31]} \\
{[31]} \\
{[32]} \\
{[24]} \\
{[33]}\end{array}$ \\
\hline $\begin{array}{l}\text { Simplification of fee payment pathways and } \\
\text { contract with international insurance }\end{array}$ & $\begin{array}{l}\text { - } \\
\text { - } \quad \text { Dentract with international insurances } \\
\text { currency for patients. } \\
\text { - } \quad \text { Coordination between care centers and banks to make electronic } \\
\text { payment ability. } \\
\text { - } \quad \text { Making transferable insurance cover } \\
\text { Existence of an structure for admitting tourists with foreign health } \\
\text { insurances }\end{array}$ & $\begin{array}{l}{[24],[32],[33]} \\
{[24]} \\
{[32]} \\
{[2],[26]} \\
{[31]}\end{array}$ \\
\hline $\begin{array}{l}\text { Government financial support and to encourage } \\
\text { investment at health tourism sector }\end{array}$ & $\begin{array}{l}\text { - To encourage investment on health tourism area } \\
\text { - } \quad \text { Coordination of public and private sectors on health tourism industry } \\
\text { - } \\
\text { - } \\
\text { - } \\
\text { - Tllocation of financial facilities through the government for hospitals } \\
\text { To encourage active institutes at health tourism sector }\end{array}$ & $\begin{array}{l}{[2],[34],[35]} \\
{[34]} \\
{[32]} \\
{[2]} \\
{[2],[31]} \\
{[26]}\end{array}$ \\
\hline $\begin{array}{l}\text { Existence of sufficient and proficient systems with } \\
\text { the objective of foreign patients attraction }\end{array}$ & $\begin{array}{l}\text { - Existence of a proficient system aiming for attracting foreign patient } \\
\text { (from internal transfers to referring to home) } \\
\text { - } \quad \text { Creating possibility of medical consultants before patients' dispatch } \\
\text { - Making referral tracks for medical tourists in countries of destination } \\
\text { - Accessibility }\end{array}$ & $\begin{array}{l}{[31]} \\
{[24]} \\
{[34]} \\
{[36]}\end{array}$ \\
\hline Developing professional staff & $\begin{array}{ll}\text { - } & \text { Pro medical staff with high social and communication skills } \\
\text { - } & \text { Staff with foreign languages skills } \\
\text { - } & \text { Staff with international work experiences and credible course licenses } \\
\text { - } & \text { Professional high skilled and knowledgeable staff }\end{array}$ & $\begin{array}{l}{[31],[33]} \\
{[32],[33]} \\
{[33]} \\
{[33]}\end{array}$ \\
\hline
\end{tabular}

At second stage, experts were chosen by combination of simple and snowball sampling. Experts' adding were continued to achieve the saturation level of information; hence, at this level 14 individuals were interviewed who were managers in 5 related area from Kish Free Zone organization include: 2 individuals from academic sector, 2 individuals from healthcare services, and 5 individuals from travel services and hotel managers of private sectors. At next step, experts were asked to express their opinions about how much each factor effect on developing of health tourism in Kish Island by choosing one of "strongly effective, effective, Neither agree nor disagree about be effective, a little effective, and strongly none effective" items. The results of experts' opinions were tested by using of one sample T test and thus, 15 factors were omitted. Also experts were asked to answer this question: "Which factors amongst all factors do you think are the most significant challenges with regard to Kish's current condition?" "Which factors among the 19 remained factors are effective on health tourism?" Matching to the experts' opinions 13 factors were identified as main challenges as are showed in table2. 
Table 2: The Health Tourism Challenges of Kish Free Zone

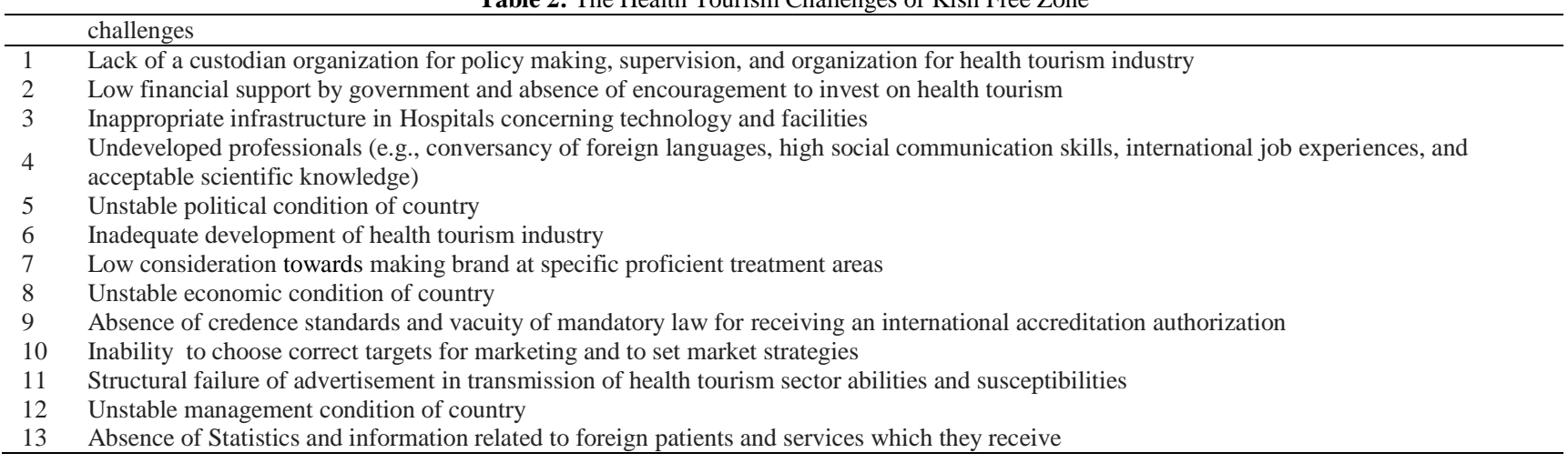

At the final stage, experts' complementary opinions regarding per challenges which were collected by semi-structured interview were gathered and analyzed by content analysis method. The modus operandi was extracting all related subthemes about the health tourism from interviews at first, and then specifying the connection between concept and content of themes and per Kish health tourism challenges. Examples of some extracted subthemes from interviews and related challenges are showed at table 3 .

Table 3: The Method of Connecting Experts' Opinions Subthemes to Effective Opportunities and Challenges in Kish Health Tourism

\begin{tabular}{|c|c|}
\hline Experts' opinion subthemes & Related challenge \\
\hline $\begin{array}{l}\text { - } \\
\text { - } \quad \text { Lack of hospital capabilities, facilities, and proficient medical staff } \\
\text { - } \quad \text { Impossibility of implementing some diagnostic and therapeutic } \\
\text { procedures in Kish's hospital } \\
\text { Differences between hospitals which are made so that the structure can be } \\
\text { suitable for giving health tourism services and hospitals made for public } \\
\text { services like Kish hospital are too many } \\
\text { Kish's health system efficiency is Incapable to offer health tourism } \\
\text { - } \quad \text { services though, is acceptable for public services } \\
\text { Both facilities and the level of quality of medical services are not } \\
\text { acceptable nor locals are satisfied with services } \\
\text { Hardware and software facilities of Kish health tourism are not } \\
\text { appropriate for health tourism purposes }\end{array}$ & $\begin{array}{l}\text { Lack of appropriate substructures according to technologies, } \\
\text { facilities, and equipment for giving appropriate health care services }\end{array}$ \\
\hline $\begin{array}{l}\text { - Holding professional courses is essential for creating high skilled human } \\
\text { resource } \\
\text { Although holding communication skills courses for all staff that are } \\
\text { connected to health tourists is essential, it hasn't done yet. } \\
\text { - There isn't any capable staff at health tourism sector in Kish Free Zone } \\
\text { currently } \\
\text { Training the trustees of health tourism to make them capable with the aim } \\
\text { of making targeted decisions } \\
\text { Codifying a tourism rights bill and to hold educational courses so as to } \\
\text { uniform tourism ethics in Kish is essential }\end{array}$ & $\begin{array}{l}\text { Undeveloped professional human resource( foreign language } \\
\text { proficiency, high social communication skills, international work } \\
\text { experience, and acceptable scientific knowledge) }\end{array}$ \\
\hline
\end{tabular}

\section{Discussion}

Identification of the challenges at Kish health tourism helps policy makers of this area, as the most thriving place among Iran's free zones, to develop health tourism by implementing more effective reformation. At this paper 13 challenges of health tourism which Kish Island encounter was distinguished additionally, all of the challenges were confirmed by the similar searches. The most significant achievement of this study was experts' complementary opinions about per challenge that must help to show a more real and clear vision of health tourism condition to policy makers accordingly, Aim at this part is to shape this vision.

\subsection{Lack of a custodian organization for policy making, supervision, and organization for health tourism industry}

There have not been codified any policy, plan, and implementable model for developing health tourism in Kish to absorb Iranian physicians who are residents in foreign countries. Some projects which have established by officials to develop health tourism were left unfinished for instance, Kish international hospital and health city. Attentions to social determinants at planning stage through codifying a dynamic plan for updating capabilities seems necessary to develop Kish health tourism. Unfortunately despite many potential, Kish Free Zone Organization neither concentrated on health 
tourism at "Kish comprehensive project" nor gave any permission to private sector with the intention of transferring charges. Government must interfere in macro policy making, education, and supervision therefore, Kish Free Zone Organization should only be a backup force and supervisor for Kish health tourism development not the executive factor. With the aim of developing Kish health tourism Kish international airport capacity should be expand and external flights establish. Currently, absorption, transfer, and distribution of tourists have been monopolized and it means a threat for tourism industry.

It can be concluded that policy making, organizing, and planning at Kish health tourism face to many macro challenges besides, absence of a proficient trustee organization which in addition to planning and policy making, be able to supervises executive activities related to health tourism area has made more intensification around this challenge.

\subsection{Low financial support by government and absence of encouragement to invest on health tourism}

As experts' opinion, government has allocated numerous facilities such as water and electricity supplies and long repayment constructive loans to health tourism in successful countries. However government has not given any of those facilities in Kish. On the contrary, it rocks the boat for health tourism projects. Kish Health tourism depends on receiving bank facilities, financial safety creation and investing assurance at this area which they must be government responsibilities.

Totally governmental support for private sector is one of the exit directions from the current situation to make health tourism progress.

\subsection{Inappropriate infrastructure in Hospitals concerning technology and facilities}

Necessary equipment and facilities do not exist in Kish hospital because of the fact that it was made for natives' needs hence, it isn't accountable to health tourism plan at international level. Despite the quality of medical tourism has been elevated at other urban cities in Iran, absence of infrastructures in Kish is responsible for immature health system. The level of Kish hospital's medical services are low as far as even natives are dissatisfied from services therefore, this condition of medical tourism in Kish has brought many issues for Kish to be able to compete with others. There has not been advertised for Kish health tourism abilities yet in addition, inability to access to some medical equipment, updated technology, and proficient human resources results in, impossibility to diagnose and offer some medical services in Kish hospital.

On the whole, Kish hospital has not enough capacity in terms of technology, facilities, and equipment to be an international health tourism provider.

\subsection{Undeveloped professionals (e.g., conversancy of foreign languages, high social communication skills, international job experiences, and acceptable scientific knowledge)}

Professionals of Kish hospital need some professional courses vitally to make them capable. However, it hasn't been scheduled for any courses in Kish hospital yet. In addition, Authorities' priorities must be codifying a proper patients' right bill and holding courses related to ethical matters in order to train all human resources who related to medical tourism even all population in Kish. Moreover, Trustees need some educations themselves to be capable of making the right purposeful decisions and Communicational educations are necessary for employees who will be involved with international patients. However, neither education has been implemented, even nor has been planned for these programs in Kish. Therefore, elevation of satisfaction in medical tourists in this situation will bring more customer in future, ignoring competence of human resources in foreign languages and communication skills could hurt medical tourism industry in Kish.

It can be conclude that promotion of human resources in Kish's current situation by developing of proficiency on foreign languages, high skills of social communication, international job experiences, and acceptable scientific knowledge, will affect positively on Kish health tourism industry.

\subsection{Unstable political condition of country}

Sanctions had affected roughly on health tourism market thus, moved it toward the competitor countries. Making sanctions tighten leads to being internal tourism transfer in the country as the only tourist resource for Kish. Lack of safety feeling is the first effect of negative advertisement fallowed by sanctions; result of these fallowing events is contact interruption between Kish and its main customers. Going up and down of political situation is responsible for management instability on health tourist absorption as a negative effect. Economic and political problems has power to affect negatively on Iranians' mind who are living in abroad for decision making if they want to choose medical travel in Iran. Sanctions decreased political affairs and consequently, effects have been being continued by decreasing the fellow of tourists transfer to Kish so far. 
Interactions of Iran with developed countries and tightening sanctions are the challenges among Kish and health tourism.

\subsection{Inadequate development of health tourism industry}

Tourists' travels should organize how they have been drawn to Kish Island for all seasons; however, they have been limited to special periods of year. Condition of drinking water is not appropriate so establishing facilities with the purpose of improving water purification must be considered. Turning Kish Island with high range of tourism attractive potentials to a tourism center needs to some predispositions and that is the reason why Kish Island has not been recognized by tourists as much as other competitor countries.

It can be concluded that, Kish has potential to be one of the most powerful tourism centers in Asia continent; however, health tourism progression in Kish seems unsatisfying thus, Current growth trend of medical tourism progression will not be accountable enough to cope with expectations at Iran's strategic plans. Since developing of health tourism heavily depends on tourism industry progression therefore, inadequate prosperity of medical tourism will remain as a challenge.

\subsection{Low consideration towards making brand at specific proficient treatment areas}

It is possible to turn specific cure specialties of Kish hospital (cardiovascular, neurology, and ophthalmology) into particular brands potentially. However, has not made any specified brands yet. The key of stability and perdurability of care services is branding and it depends on widespread effective advertisements. Notwithstanding the fact that Kish has a lot of specific medical potentials, trustees were unsuccessful to make brands and it should considers as a challenge.

\subsection{Unstable economic condition of country}

Irregular Increasing of side costs (ticket, transit of goods, water, electricity, etc.) results in growth of cost accounting and this inflation has been affecting on health tourism industry straightly so far. It could effect on foreigner investors' decisions hence, unstable situation of economy (sometimes policy) should affect negatively on health tourism industry. Experts concluded that economic instability; ongoing changes in cost range, fast alterations of exchange currency rating, and high inflation amount in country are the most serious challenges which stand between Iran and world trade areas such as health tourism market. Therefore any planning and targeting will be defeated before the start point, and investments will not be confirmed.

\subsection{Absence of credence standards and vacuity of mandatory law for receiving an international accreditation authorization}

Existence of none competitive circumstances in Iran have caused failure to establish credible standards; many necessary conditions for establishing the international standards does not exist on Kish's hospital. Although Insurance organizations with international cover are strict about them, Iran's insurance organizations do not have limitations to present services for none insured hospitals with international standards. Besides, being achieved to international standards is one of the most significant pre-conditions in order to absorb external investors of health tourism.

On the whole, Kish hospital at this situation without any international standard certification such as certification of Joint commission international (JCI) will be faced to an unsolvable challenge.

\subsection{Inability to choose correct targets for marketing and to set market strategies}

There is not any marketing in order to absorb medical tourists because of the fact that travels to Kish are often targeted as none medical but recreational. Identifying capability and maturity of target markets in addition, noticing to economic and cultural indexes are the duties of a specific organization aiming to organize and control the flow of medical tourists in correct pathway. It is necessary to have a clarified strategy with the goal of gaining a target market like the other Middle East and Asia region countries by employing strategies such as: making a synchronized progression in the cost and quality, establishment of multinational companies, etc. lack of planning for target markets is equal to absence from health tourism market for ever. Nonetheless, In Kish by all of existed capabilities has not been done planning with the intent of achieving to target markets so far.

\subsection{Structural failure of advertisement in transmission of health tourism sector abilities and susceptibilities}


Current advertisements are not systematic and principled, so that they were unable to address Kish's strength points appropriately. Preparation of infrastructures in order for starting advertisements is on the top of the list of priorities and operation of advertisement stands at the second step. Advertisements should be indirect further, participation of all press and embassies, as promotional leverages in health care progression, seems necessary. Medical tourism plans are slowoutcome therefore, promotional plans should be effective, long-lasting, and continuous.

However, in spite of the fact that prosperity of health tourism roughly depends on promotional activities, any schedule or specified structure for promotional purposes has not been established for Kish health tourism till now.

\subsection{Unstable management condition of country}

Frequent managerial changes is the reason for instability of policies and increasing of unfinished plans in Kish since last 2011 moreover, managers' antithetical ideas about health tourism have stopped entire projects at areas which they were in charge . Unfinished projects are the effects of structural transitions of management at health tourism related projects since twenty years ago. This challenge has been become to the biggest one because of the fact that as new managers start their work find some contrast ideas compared with last manager given that, they alter the plans. Despite passing the time make the managers mature for their field, capable to schedule appropriate plans, and the environment is diagnosed by them they, will be changed. The most of top managers at different fields (commercial, cultural, economic, and tourism) in Kish are opinionated at decision making. Direct plans should base on a comprehensive stable pathway that does not exist currently therefore, Managers should not been change till they can establish directions of plan and should have some authorities; these two elements are the keys by which unfinished projects could progress. Instability of managers' positions is the most important obstacle for the long and short-term planning at Kish health tourism.

\subsection{Absence of Statistics and information related to foreign patients and services which they receive}

In Iran there is not any tourism statistic and information specifically related to health tourism industry. Existence of health tourism information system is necessary in order to establish health tourism; on the contrary, yet it has not been being established. Incoordination of officials with the purpose of collecting and reporting information, lack of specified trustee for establishing an information system, and finally, inaccessibility to medical information from countries of destination are the powerful reasons for lack of a tourist information system.

Information and statistics are the prerequisites of any scheduling and policy making therefore, it is a potential challenge in direction of health tourism development.

\section{Conclusion}

Results of this paper showed that Kish Island is one of the most experienced and prosperous among the other Iran's free trade zones. On the contrary, has not been done any serious significant activity aiming to initiate health tourism industry. Researchers by relying on experts' opinions tender blow solutions to Kish Free Zone Organization's senior managers:

- Determining a trustee organization with the intent of policy making for health tourism industry as top of the priorities.

- Whole affairs of health tourism industry such as supervision, scheduling, strategic planning and etc. should be followed by an integrated trustee organization responsible to make affairs unified and allied so as to prevent parallel and plurality of works.

- $\quad$ Producing an "executive model to create and develop health tourism in Kish" by experts as soon as possible.

- Government should submit facilities like land assignment for health tourism investors, long-term payback loans with low interest in order to outfit the Kish hospital and to equip health centers, and facilitating of government's official affairs, to the end that are able to cause health tourism industry boom in Kish free zone.

- Declaring government's boundaries of authorities and duties for each governmental organization, exactly in policy, supervision, and education, definitely and clearly.

- $\quad$ Kish Free Zone Organization should encourage and protect of investment on private sectors aiming to create and equip competitive medical centers with the purpose that they may attract investors' attendance at international level.

- Appropriate marketing strategy is one of the most significant fundamental prerequisites with the objective of creating health tourism industry and developing it. Thus, Kish Free Zone Organization should notice to marketing strategies by using strategic management experts' opinions. 


\section{Acknowledgement}

Writers appreciate to Dr. Sheikhfathollhi for collaboration and consultation of the statistic tests. Also we are grateful to chief of Kish Free Zone Organization, assistant director of tourism department, and experts who collaborated with us at this study.

\section{References}

[1] TG. Ko, Medical tourism system model, International Journal of Tourism Sciences 11 (2011) 18 - 51.

[2] S. Tourani, SJ Tabibi, S Tofighi, N Shaarbafchizadeh, International trade in healthcare services in elected Asean countries; challenges and opportunities, Health Information Management 8(4) (2010).

[3] Z. Kazemi, Study of effective factors for attracting medical tourist in Iran. Research paper requirements for the MS degree, Lulea University of Technology, Netherlands (2007).

[4] F. Azadi, MR. Maleki, SJ. Tabibi, M. Azmal, and A medical tourist perception of Iranian hospital quality: Limited employee foreign language skills negatively impact communication, International Journal of Hospital Research 1(2) (2012).

[5] M. Lautier, Export of health services from developing countries: the case of Tunisia. Social Science \& Medicine. 67(1) (2008) 101-10. http://dx.doi.org/10.1016/j.socscimed.2008.01.057.

[6] B. Delgoshaei, H. Ravaghi, N. Abolhassani. Importance-performance analysis of medical tourism in Iran from medical tourists and medical services provider's perspective: 2011, Middle-East Journal of Scientific Research 12(11) (2012) 1541-7.

[7] A. Garcia-Altes, The development of health tourism services. Annals of Tourism Research 32 (1) (2005) 262-6. http://dx.doi.org/10.1016/j.annals.2004.05.007.

[8] J. Connell, Medical tourism: sea, sun, sand and... surgery, Tourism management 27 (6) (2006) 1093-100. http://dx.doi.org/10.1016/j.tourman.2005.11.005.

[9] B. Hutchinson, Medical tourism growing worldwide, University of Delaware (2005).

[10] M. Lagace, The rise of medical tourism, Harvard Business School Working Knowledge (2007) 1-2.

[11] IA. Glinos IA, R. Baeten, H. Maarse, Purchasing health services abroad: practices of cross-border contracting and patient mobility in six European countries, Health Policy 95 (2) (2010) 103-12.

[12] CJ. Schroeder, The evolution of medical tourism, InternationalThailand GCEOB, editor (2007).

[13] A. Jabbari, Designing a model for iran medical tourism, Iran University of Medical Sciences (2009).

[14] B. Mills, Jordan health systems appoint president \& ceo, http://phillipsdipisa.com/phillips-Dipisa-news/jordan-health-systems-appointspresident-ceo. Published October 2007. Accessd 2012.

[15] E. Cohen, Medical tourism in thailand, AU-GSB e-journal 1 (1) (2008) 24-37.

[16] S. Caballero, C. Mugomba, Medical tourism and its entrepreneurial opportunities-a conceptual framework for entry in to the industry. Unpublished master thesis Göteborg University (2006).

[17] SS. Andaleeb, Hospital advertising: the influence of perceptual and demographic factors on consumer dispositions. Journal of Services Marketing 8 (1) (1994) 48-59. http://dx.doi.org/10.1108/08876049410053302.

[18] AHAH. Khan, Factors influencing of tourist loyalty: A study on tourist destinations in malaysia (2013).

[19] P-T. Chen, R-H. Kung, MY. Huang, F-D. Chen, L. Pei, editors, Exploring the medical tourism development barriers and participation willingness in taiwan: An example of mainland tourist, Proceedings of World Academy of Science, Engineering and Technology, World Academy of Science, Engineering and Technology (2012).

[20] M. Jahangiri, Medical tourism industry in iran, WWW.iranhelthtourism.ir/fa/ViewNew. Published 2008 , Accessd 2012.

[21] R. Asadi, M. Daryaei, Strategies for development of Iran health tourism. Euro J Soc Sci 23 (3) (2011) 329-44.

[22] L. Rokni, A. Pourahmad, MH. Moteiey Langroudi, R. Mehdi Mahmoudi, N. Heidarzadeh, Appraisal the potential of central iran, in the context of health tourism. Iranian Journal of Public Health 42 (3) (2013) 272-9.

[23] S. Ghalami, Investigate ways to improve Iran's position in the market for health services and medical tourism attraction [Thesis], Tehran: School of Management, Tarbiat Modares University (2010).

[24] H. Salimpour, M. Tajvar, M. Arab, A survey on the current statues of exporting medical products and services to abroad in Iran, Homaye Salamat 3 (17) (2007) 12-22.

[25] A. Jabbari, MKR. Zarchi, Z. Kavosi, T. Shafaghat, A. Keshtkaran, The marketing mix and development of medical tourism in Shiraz, Mater Sociomed 25 (1) (2013) 32-6. http://dx.doi.org/10.5455/msm.2013.25.32-36.

[26] B. Delgoshaei, H. Ravaghi, N. Abolhassani, Importance-Performance analysis of medical tourism in Tehran province from medical tourists and medical services providers' perspective, Hospital 11 (1) (2012) 63-72.

[27] M. Izadi, A. Ayoobian, T. Nasiri, N. Joneidi, M. Fazel, M. Hosseinpourfard, Situation of health tourism in Iran; opportunity or threat, MilMed Journal 14 (2) (2012) 69-75.

[28] A. Ghafari, K. Ahmadi, Expert issues in Iran, MED \& LAB Engineering Magazine 6 (65) (2006).

[29] SM. Bagherifard, M. Jalali, F. Jalali, P. Khalili, S. Sharifi, Tourism Entrepreneurship Challenges and Opportunities in Mazandaran, J Basic Appl Sci Res (2013).

[30] Ministry of Foreign Affairs, Regulations of investment in commercial and industrial free zones in Islamic Republic of Iran, http://mfa.gov.ir/index.aspx?siteid=1\&pageid=22406. Published 1999, Accessd 2012.

[31] MH. Kaffash, M. Ziaee, G. Jafari, Prioritize of related factors to Iran's health tourism industry, Tourism Reaserches 11 (2005) 23-40.

[32] NS. Momtaz, Z. AghaRahimi, Medical tourism industry in Iran: solutions for developing, Health Information Management 4 special (2010) 516-24.

[33] AA. Nasiripour, L. Salmani, The role of Tehran's hospitals capability in development of medical tourism. Hospital Journal 9 (2011).

[34] J. Arunanondchai, C. Fink, Trade in health services in the ASEAN region, Health Promotion International 21 (suppl 1) (2006) 59-66. http://dx.doi.org/10.1093/heapro/dal052.

[35] [35] R. Hinnawi, Investment in medical tourism industry in MENA region, Medical Tourism \& Health Care Management Jordan [Online] (2007).

[36] SS. Harahsheh, Curative tourism in Jordan and its potential development, Bournemouth University, United Kingdom 3 (1) (2002) 45-78. 